\title{
Impact of Communication in the Management of Revenue Collection in Onitsha Metropolitan Area, Anambra State of Nigeria
}

\author{
Joseph Brown \\ Department of Management, Texila American University, Guyana City, Guyana
}

\begin{abstract}
The government needs adequate financial resources to deliver its many developmental functions. However, such financial resources are either not available or inadequate. One way of rising to this challenge has been scaling up revenue collection from local revenue sources. This study aims to assess the impact of communication in the management of revenue collection using a descriptive survey research design. The researcher formulated two research questions and one hypothesis. A selfdeveloped questionnaire was used for data collection. The sample size consists of revenue collectors in Onitsha Metropolitan Area selected using the purposive random sampling technique; subsequently, thirty copies of the questionnaire were administered by the researcher. Mean, and standard deviation was used to analyse the data. The study showed, among other findings, that communication facilitates the co-ordination of the task, which impacts the management of revenue collection. Also, there is no significant difference on the views of male and female revenue collectors regarding the impact of communication on the management of revenue collection in the Onitsha Metropolitan Area of Nigeria. These findings have the vantage of providing the researchers, policymakers, and government with adequate and correct baseline data on the impact of communication in the management of revenue collection. Conclusions were drawn from the findings, and it was recommended that training and re-training programmes for the revenue officials should be organized at regular intervals to enable them to meet the challenge of the new millennium.
\end{abstract}

Keywords: Communication, Management, Metropolitan Area, Revenue collection.

\section{Introduction}

Onitsha can be sited in Anambra, a State which came into existence in 1976 as one of Nigeria's 36 states and one of the 5 states in the country's southeast geo-political zone asides Imo, Ebonyi, Abia, and Enugu. Due to enormous political and administrative factors, Anambra State was extensively restructured in August 1991 and its former capital, Enugu, was created as a new state while Awka then became the new capital of Anambra State with 21 administrative local governments headquarters. Onitsha is a densely populated and rapidly growing merchandising city in Anambra State. Geographically, it is located on latitude $6.1^{\circ} \mathrm{N}$ and longitude $6.8^{\circ} \mathrm{E}$, and it serves as the major entry point when trying to access the eastern sector of Nigeria when coming from Lagos via Benin on the east-west highway and which as well connects the eastern north-south trail across Onitsha Niger Bridge. The city occupies the eastern bank of the Niger River, which stretches over 50 square kilometers.

The major concentration is in population, industrial activities, the areas showing the greatest potential for growth and huge revenue generation. Despite the high density of people and business activities in the Onitsha Metropolitan Area, the state continues to face major revenue collection challenges that make the government to lose billions of revenues 
annually $[1,2]$. Yuliaty identified that effective use of organizational communication in revenue collection functions is a major problem hindering the government to expand its revenue collection activities [3].

\section{Concept of Communication}

Communication involves any medium that is utilised to exchange information in an effective manner. For communication to be effective, there must be a sender (the initiator of the message), a recipient (the receiver of the message), and the verbal or non-verbal content (including signals, scripting, diagrams, and expressions) must be meaningful and clearly understood by the receiver with a minimal level of distortion [4]. More simply, communication is said to be "the creation and exchange of meaning" [5]. In spite of the fact that communication seems quite easy, yet there are several underlying factors such as the receiver's cultural background, the emotions coupled with the transmission, and the environment within which the medium was initiated.

Most of such complexities actually play a very vital role for an effective, skillful, accurate, and unambiguous message relay by revenue collectors in administering their tasks.

\section{Concept of Revenue}

Revenue is the incoming proceeds generated from normal business operations, calculated as the average sales price times the number of units sold. It may also be inferred to as the top line (or gross income) figure from which costs are subtracted to determine net income [6]. Revenue may also be identified as the sales return on an income statement. It is, actually, the value of all sales of goods and services recognized by a company within a specific period. Revenue, also referred to as Sales or Income basically forms the beginning of a company's income statement and is often considered the "Top Line" of a business. There are, however, numerous concept definitions of revenue. Fayemi briefly described government revenue as government proceeds which the legislature has a mandate to appropriate. Furthermore, he classified recurrent and capital revenue as two kinds of government income [7]. Hepworth depicted revenue as an income or funds generated to finance an item of expenditure. He portrays revenue as the means required to provide government services. He stated further that Income and Expenditure might also be classified as the dual aspects of finance, which are, primarily, the sources of fund and utilization [8]. Government Revenue constitutes a major component on a national budget [9]. Visser stated that municipal income has a great influence on a country's operation as it is the fundamental element for making financial and management policies. He further indicated that the key instrument ensuring funding is revenue and thus, "tax revenue collection should comply with best practices of equity, ability to pay, economic efficiency, convenience and certainty" [10]. Government revenue can, therefore, be inferred to as the income generated by the government from all sources within a period of time. Such financial resources enable the government to finance its spending. The Government Spending, on the other hand, depicts the nation's expenditures which are also reflected on the government budget when making fiscal policies [11].

It is worth mentioning at this juncture that individual positions represented as a source of government revenue can be reverted. In other words, a current source of income may be pronounced as obsolete, while a new source can be declared, customized, and added as a new source of revenue. A few instances of government revenue in Nigeria include the following: taxes on capital gain, companies' income, custom and excise duties, education., personal income, petroleum profit, stamp duties and value added taxes [12].

\section{Revenue Collection}

The government does not only collect revenues but may also offer incentives or 
subsidies. Such incentives can be in the form of a deduction or an exemption from tax or as discounts on credit interest rates. Any subsidy provided by the government is an implied negative revenue collection. Revenue collection is normally associates with the government organisations for billing and mobilising funds (such as taxes, miscellaneous fees, or fines), including debts owned by individual members of the public or by corporate bodies [13]. An effective government collection agency ensures a positive generation of municipal income and affluence on the management of the nation's fiscal policy and operations.

\section{Concept of Management}

Management is a process through which entities (such as organisations, Products, human resources, objects, etc.) are directed and controlled in order to attain a predefined set of targets. It oversees the activities of setting organizational strategies and coordination of employees or of volunteers' efforts in order to accomplish its objectives through the application of available resources, such as financial, natural, technological, and human resources [14]. Local governments were dependent primarily on the federal and state governments' statutory allocations of funds. Revenues that are internally generated, however, constitute only a small proportion of local government funds.

Such revenue includes registration of business premises, billboards, park fees, vehicle licence fees, tenement/property rates, marriage registration fees, etc. Fraud and corruption have made it difficult for local governments to deliver services to the people [15].

\section{Transparency, Resource Mobilisation and Conflict of Interest}

The local government administration is characterized by a lack of openness and transparency, the core ingredients for the democracies, for the market economies to function appropriately, and the primary key to build accountability and trust. Nigeria's local governments have generally found it extremely difficult to optimise revenue collection due to fraud, especially by revenue collectors, lack of manpower, and the crude methods of revenue collection [16]. Ajayi further highlighted that several sources that should be paying rates have actually been compromised, resulting to evading payments. As much as half of the revenue collected is thereby lost through "leakage," where the local government revenue collecting staff pockets the revenue rather than depositing it into a government account, a true scenario of conflicting interest.

This scenario is then reflected in the nonpublication of annual accounts, lack of proper auditing of local government accounts, inefficiency and fraud in revenue collection and revenue mobilisation, political interference, and lack of merit-based appointments and promotion of staff and conflicts of interest. The above foregoing background reveals that previous studies failed to give much emphasis on the impact of communication in the management of revenue collection. Previous research studies were also carried out in different organizations, and hence the findings cannot be used to establish revenue collection challenges at Onitsha Metropolitan Area. It is, therefore, against this background that this current study was undertaken; to fill the missing knowledge gap in the literature, by analyzing the impact of communication in the management of revenue collection in Onitsha Metropolitan Area, Anambra State.

\section{Materials and Methods}

This caption elaborates on the purpose of the study, the research questions, the Hypothesis that guided the study, the methods of data collection followed, the responds to the question, and how the problem was studied.

\section{Purpose of the Study}

The main purpose of this study is to survey the impact of communication in the 
management of revenue collection in the Onitsha Metropolitan Area, Anambra State. Specifically, it aims to:

1. Determine the impact of communication in the management of revenue collection in the Onitsha Metropolitan Area.

2. Ascertain strategies to enhance communication flow for effective management of revenue collection in the Onitsha Metropolitan Area.

\section{Research Questions}

The following research questions were formulated to guide the study:

1. To what extent do communication impact the management of revenue collection in the Onitsha Metropolitan Area?

2. What are the strategies to enhance communication flow for effective management of revenue collection in the Onitsha Metropolitan Area?

\section{Hypothesis}

The study is guided by the following hypothesis: There is no significant difference on the views of male and female revenue collectors regarding the impact of communication on the management of revenue collection in the Onitsha Metropolitan Area.

\section{Design of the Study}

For the purpose of this study, a descriptive research design was adopted. A survey was conducted on a few groups of people which was considered to be representative of the entire group [17]. The collected data was then analyzed, and the inference was made thereon. I decided to choose this design because this technique has been used successfully in similar studies.

\section{Area of the Study}

This research was carried out at the Onitsha Metropolitan Area located on the eastern bank of the Niger River in Anambra State, Nigeria. The city is famous for its river port which serves as an economic focal point for commence, industry and education. Furthermore, the city proudly provides the largest market platform in terms of its geographical size and volume of goods traded in African.

\section{Population, Sample, and Sampling Techniques}

The target population for this study was the revenue collectors in Onitsha Metropolitan Area, Anambra State. The sample of the study consists of thirty (30) revenue collectors selected through purposive sampling techniques, this comprised nineteen (19) males and eleven (11) females.

\section{Instrument for Data Collection}

The instrument used for data collection was a questionnaire titled: 'Communication and Revenue Management Scale (CRMS). The CRMS contained twenty items in cluster A on a four-point scale of VHE - Very High Extent (4), HE - High Extent (3), LE - Low Extent (2), VLE - Very Low Extent (1), and cluster B on a four-point scale of strongly agreed $(\mathrm{SA}=4)$, Agreed $(A=3)$, Disagreed $(D=2)$ and Strongly Disagreed $(\mathrm{SD}=1)$. The overall theme of the items was based on the impact of communication in the management of revenue collection in Onitsha Metropolitan Area, Anambra State.

\section{Validation of the Instrument}

In order to determine the features and effective results of the research tool, the questionnaire was handed over to two persons with special skills in measurement and evaluation to examine and make necessary corrections and remarks. These experts were then given the purpose of the study and the research questions, alongside with the questionnaire items, to examine and make necessary corrections and remarks.

Their input was used by the researchers to modify the items of the questionnaire before the final draft. 


\section{Reliability of the Instrument}

The researchers used five (5) revenue collectors in Awka who were not participating in the main study. A copy of the questionnaire was then given to each of them to fill out, and these were immediately collected then after. The elements consisting of the questionnaire were remixed, reorganised, and then redistributed to the same teacher counsellors a fortnight later. The newly created questionnaires were collected after then and verified again using the test-retest reliability method. The mutual relationship between the scores of data collected were connected using Person-Product-Moment Correlation.

\section{Method of Data Collection}

The researcher administered the questionnaire personally. $\mathrm{He}$ administered 30 copies of the questionnaire to the selected respondents. They were collected from the respondents almost immediately after each completion; 30 copies of the questionnaire were retrieved, which yielded $100 \%$.

\section{Method of Data Analysis}

In analysing the data, the researchers used Mean \& Standard Deviation in answering the research questions. The acceptance point for the items stood at 2.5 Mean score equally (i.e., $\mathrm{SA}^{4}$, $\mathrm{SA}^{3}, \mathrm{SD}^{2}, \mathrm{D}^{1}$ ) totalling 10. Therefore, the Mean score equal $\frac{10}{4}=2.5$. Also, t-test statistics was also used to test for the hypothesis.

\section{Results}

Table 1 depicts the results of Research question 1: To what extent do communication impact the management of revenue collection in Onitsha Metropolitan Area?

Table 1. Arithmetic Mean and Standard Dispersion of Responses on the Extent to which Communication Impact the Management of Revenue Collection

\begin{tabular}{|l|l|l|l|l|l|}
\hline I/N & Item & \multicolumn{2}{|l|}{ Male } & \multicolumn{2}{l|}{ Female } \\
\cline { 3 - 6 } & & $\overline{\boldsymbol{x}}$ & STD & $\overline{\boldsymbol{x}}$ & STD \\
\hline Item 1 & $\begin{array}{l}\text { Communication promotes motivation by informing and } \\
\text { clarifying the employees about the task to be done, the } \\
\text { manner they are performing the task, and how to improve } \\
\text { their performance. }\end{array}$ & 3.21 & 0.89 & 3.18 & 0.94 \\
\hline Item 2 & $\begin{array}{l}\text { Communication facilitates the co-ordination of the task, } \\
\text { which impacts the management of revenue collection. }\end{array}$ & 3.53 & 0.82 & 3.27 & 0.96 \\
\hline Item 3 & $\begin{array}{l}\text { Communication is a source of information to the } \\
\text { organizational members for the decision-making process as } \\
\text { it helps identifying and assessing alternative courses of } \\
\text { action. }\end{array}$ & 3.16 & 0.87 & 3.00 & 0.95 \\
\hline Item 4 & $\begin{array}{l}\text { Communication provides a complete understanding of the } \\
\text { employees' job as well as to communicate to them how their } \\
\text { job is related to other jobs in the organization. }\end{array}$ & 2.21 & 1.15 & 2.64 & 1.07 \\
\hline Item 5 & $\begin{array}{l}\text { Communication helps in socializing, leading to less } \\
\text { industrial unrest, which impacts the management of revenue } \\
\text { collection. }\end{array}$ & 2.63 & 1.22 & 2.73 & 1.14 \\
\hline Item 6 & $\begin{array}{l}\text { Communication helps in controlling organizational } \\
\text { member's behaviour, increase employee engagement, and } \\
\text { higher levels of creativity which impact the management of } \\
\text { revenue collection. }\end{array}$ & 3.16 & 1.04 & 2.73 & 1.14 \\
\hline $\begin{array}{l}\text { Communication helps in solving various organizational } \\
\text { problems, improves acceptance of change, and decrease }\end{array}$ & 2.21 & 1.06 & 2.64 & 1.07 \\
\hline
\end{tabular}




\begin{tabular}{|l|l|l|l|l|l|}
\hline & $\begin{array}{l}\text { absenteeism which impact the management of revenue } \\
\text { collection. }\end{array}$ & & & & \\
\hline Item 8 & $\begin{array}{l}\text { Communication facilitates information sharing, lessens the } \\
\text { chances for misunderstandings, and potentially reduces } \\
\text { grievances and lawsuits which impact the management of } \\
\text { revenue collection. }\end{array}$ & 3.47 & 0.75 & 2.91 & 0.79 \\
\hline Item 9 & $\begin{array}{l}\text { Communication builds employee morale, satisfaction, and } \\
\text { engagement which impact the management of revenue } \\
\text { collection. }\end{array}$ & 3.53 & 0.88 & 2.18 & 1.27 \\
\hline Item 10 & $\begin{array}{l}\text { Proper communication systems ensure reliable media flow } \\
\text { throughout the organization structure which impacts the } \\
\text { management of revenue collection. }\end{array}$ & 3.16 & 0.81 & 2.27 & 1.14 \\
\hline \begin{tabular}{l} 
Total \\
\hline
\end{tabular} & $\mathbf{3 0 . 2}$ & $\mathbf{9 . 4 9}$ & $\mathbf{2 7 . 5 5}$ & $\mathbf{1 0 . 4 7}$ \\
\hline
\end{tabular}

Table 2 shows results of Research Question 2: What are the strategies to enhance communication flow for effective management of revenue collection in the Onitsha Metropolitan Area?

Table 2. Arithmetic Mean and Standard Dispersion of Responses of Male and Female Revenue Collectors on Strategies to Enhance Communication Flow for Effective Management of Revenue Collection

\begin{tabular}{|c|c|c|c|c|c|}
\hline \multirow[t]{2}{*}{$\mathbf{I} / \mathbf{N}$} & \multirow[t]{2}{*}{ Item } & \multicolumn{2}{|l|}{ Male } & \multicolumn{2}{|c|}{ Female } \\
\hline & & $\bar{x}$ & STD & $\overline{\boldsymbol{x}}$ & STD \\
\hline Item 11 & $\begin{array}{l}\text { Creating an open communication environment enhances } \\
\text { communication flow for effective revenue collection } \\
\text { management. }\end{array}$ & 3.05 & 0.83 & 3.09 & 1.00 \\
\hline Item 12 & $\begin{array}{l}\text { Engaging all employees by employing the inclusive } \\
\text { communication strategy enhances communication flow } \\
\text { for effective management of revenue collection. }\end{array}$ & 3.05 & 0.69 & 2.91 & 1.31 \\
\hline Item 13 & $\begin{array}{l}\text { Employing multiple channels to transfer messages } \\
\text { enhances communication flow to effectively manage } \\
\text { revenue collection. }\end{array}$ & 3.16 & 0.87 & 2.82 & 1.03 \\
\hline Item 14 & $\begin{array}{l}\text { Communicating objectives and goals with every } \\
\text { department enhance communication flow for effective } \\
\text { management of revenue collection. }\end{array}$ & 2.32 & 1.17 & 3.09 & 1.16 \\
\hline Item 15 & $\begin{array}{l}\text { Ensuring clarity in all communication enhances } \\
\text { communication flow for effective management of revenue } \\
\text { collection. }\end{array}$ & 2.68 & 1.22 & 2.82 & 1.11 \\
\hline Item 16 & $\begin{array}{l}\text { Prioritizing company culture and linking the } \\
\text { organizational communication plan to the business } \\
\text { strategy enhances communication flow for effective } \\
\text { management of revenue collection. }\end{array}$ & 3.11 & 1.07 & 2.82 & 1.11 \\
\hline Item 17 & $\begin{array}{l}\text { Using technology to facilitate communications enhances } \\
\text { communication flow for effective management of revenue } \\
\text { collection. }\end{array}$ & 2.53 & 1.23 & 2.73 & 1.05 \\
\hline Item 18 & $\begin{array}{l}\text { Providing opportunities for feedback enhances } \\
\text { communication flow for effective management of revenue } \\
\text { collection. }\end{array}$ & 3.42 & 0.82 & 3.27 & 0.96 \\
\hline
\end{tabular}




\begin{tabular}{|l|l|l|l|l|l|}
\hline Item 19 & $\begin{array}{l}\text { Celebrating achievements and milestones enhances } \\
\text { communication flow for effective management of revenue } \\
\text { collection. }\end{array}$ & 3.42 & 1.04 & 2.27 & 1.29 \\
\hline Item 20 & $\begin{array}{l}\text { Taking time to listen enhances communication flow for } \\
\text { effective management of revenue collection. }\end{array}$ & 2.79 & 1.00 & 2.18 & 1.11 \\
\hline & Total & $\mathbf{2 9 . 5 3}$ & $\mathbf{9 . 9 4}$ & $\mathbf{2 8}$ & $\mathbf{1 1 . 1 3}$ \\
\hline
\end{tabular}

Table 1 shows the extent to which communication impacts the management of revenue collection in the Onitsha Metropolitan Area. The results indicate that communication facilitates the co-ordination of the task, which impacts revenue collection management (Male $=3.53$, Female $=3.27$ ). It is obvious that communication promotes motivation by informing and clarifying the employees about the task to be done, the manner they are performing the task, and how to improve their performance $\quad($ Male=3.21, $\quad$ Female=3.18). Meanwhile, the female respondents disagreed that proper communication systems ensure reliable media flow throughout organization structure which impacts the management of revenue collection (2.27). In all, items $1-8$ having to mean score of 3.18, 3.27, 3.00, 2.64, $2.73,2.73,2.64$ and 2.91corresponding to standard deviation of $0.94,0.96,0.95,1.07$, $1.14,1.14,1.07$ and 0.79 were respectively accepted, while item 9 and 10 with mean score of 2.18 and 2.27 corresponding to standard deviation of 1.27 and 1.14 were respectively rejected by the female respondents. For the male respondents, items $1,2,3,5,6,8,9$, and 10 having a mean score of $3.21,3.53,3.16$, $2.63,3.16,3.47,3.53$, and 3.16 corresponding to standard deviation of $0.89,0.82,0.87,1.22$, $1.04, \quad 0.75,0.88$ and 0.81 were accepted respectively, while item 4 and 7 with a mean score of 2.21 and 2.21 corresponding to standard deviation of 1.15 and 1.06 were rejected respectively.

From table 2, the respondents agreed that providing opportunities for feedback enhances communication flow for effective management of revenue collection (Male $=3.42$, Female=3.27). However, female respondents agreed that communicating objectives and goals with every department enhances communication flow for effective management of revenue collection (3.09), whereas their male counterparts disagreed with a mean score of (2.32). Meanwhile, the female respondents disagreed that celebrating achievements and milestones enhances communication flow for effective management of revenue collection (2.27), whereas their male counterparts agreed with a mean score of (3.42). On the whole, items 11 - 18 with mean score of $3.09,2.91$, $2.82, \quad 3.09, \quad 2.82, \quad 2.82, \quad 2.73$ and 3.27 corresponding to standard deviation of 1.00 , $1.31,1.03,1.16,1.11,1.11,1.05$ and 0.96 were accepted, respectively, and item 19 and 20 with a mean score of 2.27 and 2.18 corresponding to standard deviation of 1.29 and 1.11 was rejected respectively by the female respondents, while items 11, 12, 13, 15, 16, 17, 18, 19 and 20 with a mean score of $3.05,3.05,3.16,2.68$, $3.11,2.53,3.42,3.42$ and 2.79 corresponding to standard deviation of $0.83,0.69,0.87,1.22$, $1.07,1.23,0.82,1.04$ and 1.00 , and item 14 with a mean score of 2.32 corresponding to standard deviation of 1.17 were rejected respectively by the male respondents.

Hypothesis 1: There is no significant difference on the views of male and female revenue collectors regarding the impact of communication on the management of revenue collection in the Onitsha Metropolitan Area. 
Table 3. Summary of t-test on Male and Female Revenue Collectors regarding the Impact of Communication on the Management of Revenue Collection

\begin{tabular}{|l|l|l|l|l|l|l|l|}
\hline Source & N & Mean & Std. dev & t-Cal & t-crit & $\mathbf{d}_{f}$ & P. Value \\
\hline Male & 19 & 30.27 & 9.49 & 0.709 & 2.0484 & 28.00 & 0.4842 \\
\cline { 1 - 6 } Female & 11 & 27.55 & 10.47 & & & & \\
\hline
\end{tabular}

$\operatorname{Sig}<0.05$

Table 3 shows that at 0.05 level of significance and $28^{\circ}$ of freedom, the calculated $\mathrm{t}=0.709$ is less than the critical $\mathrm{t}=2.0484$. Therefore, the null hypothesis is accepted, the researcher concludes that there is no significant difference on the views of male and female revenue collectors regarding the impact of communication on the management of revenue collection in the Onitsha Metropolitan Area. Research question 1 sought to find out the extent of communication impact on the management of revenue collection in the Onitsha Metropolitan Area. The study found that communication facilitates coordination of the task, which impacts revenue collection management. This view has previously been promulgated by Sausi, Kitali \& Mtebe, who observed revenue as all tools of income to the government to which the legislature has the power of appropriation such as taxes, rates, fees, fines, duties, penalties, rents, dues, proceeds, and other receipts of government. $\mathrm{He}$ further classified government revenue into two kinds: recurrent revenue and capital revenue [1]. Zhou \& Madhikeni maintains that communication promotes motivation by informing and clarifying the employees about the task to be done, the manner they are performing the task, and how to improve their performance [18]. He also implies that proper communication systems ensure reliable media flow throughout the organization structure, which impacts revenue collection management.

Research question 2 dealt with the strategies to enhance communication flow for effective management of revenue collection in the Onitsha Metropolitan Area. Based on the analysis, the respondents agreed that providing opportunities for feedback enhances communication flow for effective management of revenue collection. Fang, Cassim, Hsu, and Chen noted that the use of peer feedback enhanced oral communication [19].

However, celebrating achievements and milestones enhances communication flow for effective management of revenue collection. In most cases, employing multiple channels to transfer messages enhances communication flow for effective management of revenue collection. Finally, Sutiyatno opined that prioritizing company culture and linking the organizational communication plan to the business strategy enhances communication flow for effective management of revenue collection [20]. Culture creates and influences the environmental framework in which an organization operates. It also determines the nature of the strategic plans that inevitably propel the organization towards its vision of efficient revenue mobilization and administration. In most cases, the corporate culture largely dictates the traditions, policies, economic trends, business processes, international trade, company size, etc. and enable the organization to live out its mission on a daily basis.

\section{Discussion}

Research question 1 sought to find out to what extent do communication impacts the management of revenue collection in the Onitsha Metropolitan Area. The study found that communication facilitates the co-ordination of the task, which impacts the management of revenue collection. This view has previously 
been promulgated by Sausi, Kitali \& Mtebe [1], who observed revenue as all income instruments of a government from taxes, excise duties, penalties, or other sources which the legislature deemed to the payment of public expenses. Broadly speaking, the government revenue may further be categorized into recurrent revenue and capital revenue. Zhou \& Madhikeni maintains that communication promotes motivation by informing and clarifying the employees about the task to be done, the manner they are performing the task, and how to improve their performance [17]. He also implies that proper communication systems ensure reliable media flow throughout organization structure which impacts the management of revenue collection.

Research question 2 dealt with the strategies to enhance communication flow for effective management of revenue collection in the Onitsha Metropolitan Area. Based on the analysis, the respondents agreed that providing opportunities for feedback enhances communication flow for effective management of revenue collection. Fang, Cassim, Hsu, and Chen noted that the use of peer feedback enhanced oral communication [18]. However, celebrating achievements and milestones enhances communication flow for effective management of revenue collection. In most cases, employing multiple channels to transfer messages enhances communication flow for effective management of revenue collection.

Finally, Sutiyatno opined that prioritizing company culture and linking the organizational communication plan to the business strategy enhances communication flow for effective management of revenue collection [19]. Culture creates and influences the environmental framework in which an organisation operates. It also determines the nature of the strategic plans that inevitably propel the organization towards its vision of efficient revenue mobilization and administration. In most cases, the corporate culture largely dictates the traditions, policies, economic trends, business processes, international trade, company size, etc., and enables the organization to live out its mission daily.

\section{Conclusion}

The study has been able to examine the impact of communication in the management of revenue collection in the Onitsha Metropolitan Area, Anambra State. The results of this study have shown that communication facilitates coordination of the task, which impacts the management of revenue collection; communication builds employee morale, satisfaction, and engagement, impacting the management of revenue collection. The findings also revealed that providing opportunities for feedback enhances communication flow for effective management of revenue collection. The study also made it clear that celebrating achievements and milestones enhances communication flow for effective management of revenue collection.

\section{Educational Implications}

The insight acquired from this study has immense significance for education. The study findings will create an open communication environment that enhances communication flow for effective management of revenue collection. The study, therefore, may be helpful by creating an open communication environment that enhances effective communication flow. Government leaders can leverage the findings of this study to inspire others and maintain a climate to enhance communication flow for effective management of revenue collection in the Onitsha Metropolitan Area.

\section{Recommendations}

Based on the findings and the conclusion arising from the study, the following recommendations are hereby made:

1. The local government chairman should ensure that machinery be in place to generate more revenue internally to enable them to do more development projects. 
2. Training and re-training programs for the revenue officials should be organized to enable them meets the challenge of the new millennium.

3. Competent hands should be employed in the revenue section.

4. Enlightenment campaigns on the revenue to be paid by an individual should be carried out.

5. Control measures should be put in place to check possible frauds and embezzlement.

6. Automating and digitalizing the process of revenue collections will enhance efficient and effective service provision coupled with high customer satisfaction.

\section{References}

[1] Sausi, J. M., Kitali, E. J., \& Mtebe, J. S. (2021). Evaluation of local government revenue collection information system success in Tanzania. Digital Policy, Regulation, and Governance.

[2] Obiaso, C. B., Odumu, W. R., \& Iyenagbe, F. O. (2021). Impact of high taxes on the performance of small and medium scale businesses in anambra state. International Journal of Management and Entrepreneurship, 3(1), 276-306.

[3] Yuliaty, F. (2021). The Importance of Organizational Communication in Improving Employee Performance: A Case Study of the Regional Revenue Management Agency of the City of Bandung. International Journal of Science and Society, 3(1), 361-370.

[4] Balconi, M., \& Fronda, G. (2020). The use of hyperscanning to investigate the role of social, affective, and informative gestures in non-verbal communication. Electrophysiological (EEG) and inter-brain connectivity evidence. Brain sciences, 10(1), 29.

[5] Sutiyatno, S. (2018). The effect of teacher's verbal communication and non-verbal communication on students' English achievement. Journal of Language Teaching and Research, 9(2), 430-437.

\section{Acknowledgements}

I wish to thank God Almighty for making it possible for me to complete this journal. I offer my appreciation for the learning opportunities provided by my special mentor Ms. Anitha. A, \& Ms. Mayuri Meha GV.

To the respondents from the Onitsha Metropolitan Area of Anambra State of Nigeria, who participated in my research, I am thankful. To my employer, German Academic Exchange Service $(D A A D e V)$. I am grateful.

Lastly, I cannot express enough thanks to my family for their encouragement: my wife Lucy Wairimu, my son Joseph Jr., and my daughter Seraphin.

Thank you. Joseph Brown.

[6] Adu-Gyamfi, E. (2014). Effective revenue mobilisation by districts assemblies: A case study of Upper Denkyira East Municipal Assembly of Ghana. Public Policy and Administration Review, 2(1), 97-122.

[7] Fayemi, O. A. (1991). Principle of Local Government Accounting Chapter Ten Publication Ltd, Yaba-Lagos.

[8] Hepworth, N.P. (1976). the finance of local government, Gorge Allen, London.

[9] Nwosu, D. C., \& Okafor, H. O. (2014). Government revenue and expenditure in Nigeria: A disaggregated analysis. Asian Economic and Financial Review, 4(7), 877.

[10] Visser, C, B. and Erasmus, P, W. (2005). The Management of Public Finance: A Practical Guide Oxford University Press: Oxford.

[11] Nwosu, D. C., \& Okafor, H. O. (2014). Government revenue and expenditure in Nigeria: A disaggregated analysis. Asian Economic and Financial Review, 4(7), 877.

[12] Odimegwu, C. N., \& Igwe, C. (2020). Adequate tax policy and implementation: a panacea to the success of a property tax system. a case of the failed anambra state property and land use charge (APLUC). Tropical Built Environment Journal, $7(1)$. 
[13] Odoyo, C. O., Moses, O., John, M. O., Aila, F. O., Ojera, P. B., \& Siringi, E. M. (2013). Effect of information systems on revenue collection by local authorities in Homa Bay County, Kenya. Universal Journal of Accounting and Finance, 1(1), 29-33.

[14] Ngotho, J., \& Kerongo, F. (2014). Determinants of revenue collection in developing countries: Kenya's tax collection perspective. Journal of management and business administration, 1(1), 1-0.

[15] Koskei, A., Cheruiyot, P., \& Naibei, I. (2019). Revenue Collection Efficiency in the County Government of Kericho, Kenya. East African Journal of Business and Economics, 1(1), 9-21.

[16] Ajayi, M. O., Ejindu, C, E., Okoyjie, C. C., Ikenna, U. C., (2007). Structure Plan for Onitsha and Satellite Towns. State Economic Empowerment and Development Strategies (SEEDS), Anambra State Government Printer Awka., Second Edition, 32-33.

[17]Nworgu, B.G (2015). Educational research. Basic issues \& methodology (3rd ed.). Nsukka: University Trust Publishers.

[18]Zhou, G., \& Madhikeni, A. (2013), Systems, Processes and Challenges of Public Revenue Collection in Zimbabwe. American International Journal of Contemporary.

[19]Fang, W. C., Cassim, F. A., Hsu, C. N., \& Chen, N. S. (2018). Effects of reciprocal peer feedback on EFL learners' communication strategy use and oral communication performance. Smart Learning Environments, 5(1), 1-16.

[20] Sutiyatno, S. (2018). The effect of teacher's verbal communication and non-verbal communication on students' English achievement. Journal of Language Teaching and Research, 9(2), 430-437.

[21] Ezeabasili, A. C. C., Anike, O. L., \& Okonkwo, A. U. (2014). Management of urban water for domestic and industrial uses and sustainability in Anambra State, Nigeria. International Journal of Water Resources and Environmental Engineering, 6(8), 212-219.

[22] Anambra State Local Government System, (2007). Onitsha South Local Government Area: Local Economic Empowerment and Development Strategy (LEEDS), $1^{\text {st }}$ Edition.

[23] Anambra State Local Government System, (2007a). Onitsha North Local Government Area: Local Economic Empowerment and Development Strategy (LEEDS). 